Volkan TEMizKAN, M. Ali YETGíN \& Kasım YILMAZ, 2022, Cilt: 23, Sayı: 1, ss. 25-48.

\author{
Cumhuriyet University \\ Journal of Economics and Administrative Sciences \\ E-ISSN: 2687-4032
}

2022, 23(1), pp.25-48.

Doi: 10.37880/cumuiibf.987656

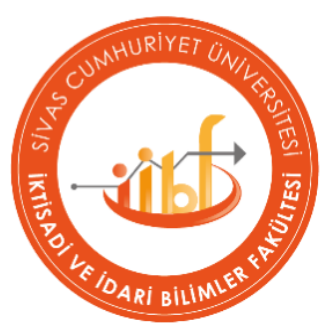

\title{
MOTIVATIONS OF RETAILERS ACCEPTING CRYPTOCURRENCY PAYMENTS AND THEIR IMPLICATIONS ON RETAIL CUSTOMER EXPERIENCE
}

\section{Volkan TEMIZKAN ${ }^{1}$ \\ Muhammed Ali YETGIN'² \\ Kasım YILMAZ ${ }^{3}$}

\section{Abstract}

The level of technology use of humanity has increased, while the interest in digital assets has increased with the effect of the pandemic period. This increasing interest has led to curiosity about what kind of consumer experience cryptocurrencies will offer when used in retail shopping. Cryptocurrencies, which have attracted a high level of interest from investors for the last four years, have become even more the focus of attention with the ongoing pandemic in 2020, increasing its value and use. In addition, there are more than 17 thousand crypto money ATMs in 68 countries worldwide, and the number is increasing day by day. This study aims to reveal the advantages and disadvantages of using cryptocurrencies in shopping based on the experiences of businesses that accept payments with cryptocurrencies. Interviews were conducted with nine business companies in Turkey that accept payments with crypto money using the in-depth interview technique in this study. A total of nine business companies that accepted the interview were informed that the interviews would be conducted via video conference over the Zoom program, and permission was obtained to record the interview data. A research model was proposed due to the content analysis carried out with the NVivo analysis program for the findings. This research points out that consumers and retailers prefer cryptocurrencies because they are a fast, safe, and cheap global payment tool. However, it has been found that there are also consumers who are unaware of payments with cryptocurrencies. Some consumers do not prefer payments with cryptocurrencies either because of low technology usage levels or lack of trust in the system. However, when necessary legal subregulations are made, and everything is digitized, money will also become digital in the common opinion. Unlike the studies in the literature, as a result of this study, it is predicted that payments with crypto money will be one of the alternative payment tools of the future after the cryptocurrencies are positioned on a legal platform by the official authorities.
Article History:

Date submitted:

26 August 2021

Date accepted:

17 November 2021

Jel Codes:

M10, M19, M20, M30,

M31

Keywords:

Using

Cryptocurrencies as a

Payment Method,

Cryptocurrency

Payments in Retailing,

Diffusion of

Innovations Theory

Suggested Citation: Temizkan, V., Yetgin, M. A. \& Y1lmaz K. (2022). Motivations of Retailers Accepting Cryptocurrency Payments and Their Implications on Retail Customer Experience. Cumhuriyet University Journal of Economics and Administrative Sciences, 23(1), 25-48.

${ }^{1}$ Asst. Prof. Dr., University of Karabuk, Vocational School of Social Sciences, vtemizkan@karabuk.edu.tr, ORCID ID: 0000-0002-1162-7912

${ }^{2}$ Asst. Prof. Dr., University of Karabuk, Vocational School of Social Sciences, m.ali.yetgin@karabuk.edu.tr, ORCID ID: 0000-0002-8120-4704, (Corresponding Author)

3 Asst. Prof. Dr., University of Karabuk, TOBB Vocational School of Technical Sciences, kasimyilmaz@karabuk.edu.tr, ORCID ID: 0000-0002-4544-4727 


\author{
Cumhuriyet Üniversitesi \\ Iktisadi ve Idari Bilimler Dergisi \\ E-ISSN: 2687-4032 \\ 2022, 23(1), pp.25-48. \\ Doi: $10.37880 /$ cumuiibf.987656
}

\title{
KRİPTO PARA İLE ÖDEME KABUL EDEN PERAKENDECILLERIN MOTIVASYONLARI VE MÜŞTERI DENEYIMINE İLIŞKIN GÖZLEMLERI
}

\section{Volkan TEMIZKAN ${ }^{1}$ \\ Muhammed Ali YETGIN² \\ Kasım YILMAZ ${ }^{3}$}

\section{$\ddot{O} z$}

Pandemi döneminin etkisiyle birlikte insanlığın teknoloji kullanım düzeyi artar iken dijital varlıklara olan ilgisi de artmıştır. Tüketicilerin artan bu ilgisi kripto paraların perakende alışverişlerde kullanıldığında nasıl bir tüketici deneyimi sunacağının merak edilmesine neden olmuştur. Son dört yıldır yatırımcıların da yüksek seviyede ilgisini çeken kripto paralar, 2020 yılında süregelen pandemi ile daha da ilgi odağı olmuş, değerini ve kullanımını artırmıştır. Ayrıca şu an dünya üzerinde 68 ülkede 17 binden fazla kripto para ATM'si bulunmakta ve her geçen gün sayısı artmaktadır. Bu çalı̧̧ma kripto para ile ödeme kabul eden işletmelerin deneyimlerinden hareketle alışverişlerde kripto para kullanımının avantaj ve dezavantajlarını ortaya koymayı amaçlamaktadır. Bu çalışmada derinlemesine mülakat tekniği kullanılarak Türkiye'de kripto para ile ödeme kabul eden yetmişdokuz işletme içerisinden görüşmeyi kabul eden dokuz işletme ile görüşmeler gerçekleştirilmiştir. Görüşmeyi kabul eden toplam dokuz işletmeye, görüşmelerin Zoom programı üzerinden video-konferans yoluyla yapılacağı bilgisi verilmiş ve görüşme verilerinin kayıt altına alınması için izin alınmıştır. Elde edilen bulgulara yönelik NVivo analiz programı ile gerçekleştirilen içerik analizi sonucunda da bir araştırma modeli önerilmiştir. Buna göre kripto paraların hızl, güvenli, ucuz ve global bir ödeme aracı olmast tercih sebebi olmaktadır. Ancak kripto ödeme yöntemlerinden haberi olmayan ya da haberi olsa da teknoloji kullanım seviyesi zaylf olduğundan veya güvenilir bulmadiğından dolayı kullanmayan tüketicilerin varlı̆̆ının da olduğu sonucuna ulaşılmıştır. Ancak bütün tarafların ortak düşüncesi her şeyin dijitalleştiği bir ortamda gerekli yasal alt düzenlemeler yapıldiğında paranında dijitalleşeceğidir. Literatürdeki çalışmalardan farklı olarak, bu çalışmanın sonucunda pandemi döneminin dijitalleşmeye olan etkisi ile kripto paraların resmi yetkililer tarafindan yasal bir platformda konumlandirmasinın ardından, kripto para ile ödemelerin geleceğin alternatif ödeme araçlarından biri olacă̆ı öngörüsüdür.

Önerilen Alıntı: Temizkan, V., Yetgin, M. A. \& Y1lmaz K. (2022). Kripto Para ile Ödeme Kabul Eden Perakendecilerin Motivasyonları ve Müşteri Deneyimine İlişkin Gözlemleri. Cumhuriyet Üniversitesi İktisadi ve İdari Bilimler Dergisi, 23(1), 25-48.

${ }^{1}$ Dr. Öğr Üyesi, Karabük Üniversitesi, Sosyal Bilimler Meslek Yüksekokulu, vtemizkan@karabuk.edu.tr, ORCID ID: 0000-0002-1162-7912

${ }^{2}$ Dr. Öğr Üyesi, Karabük Üniversitesi, Sosyal Bilimler Meslek Yüksekokulu, m.ali.yetgin@karabuk.edu.tr, ORCID ID: 0000-0002-8120-4704, (Sorumlu Yazar)

${ }^{3}$ Dr. Öğr Üyesi, Karabük Üniversitesi, TOBB Teknik Bilimler Meslek Yüksekokulu, kasimyilmaz@karabuk.edu.tr, ORCID ID: 0000-0002-4544-4727 
Volkan TEMizKAN, M. Ali YETGíN \& Kasım YILMAZ, 2022, Cilt: 23, Sayı: 1, ss. 25-48.

\section{INTRODUCTION}

Money, an essential tool in human history for centuries, has started to be transforming into cryptocurrencies lately, which can be stored, transferred, and used in expenditures in the digital environment. The first basic idea of digital money was handled in terms of the safety of consumers, where truck and trailer drivers were able to buy fuel with smart cards loaded with money to protect them against crimes such as theft and extortion during their resting processes in gas stations at the end of 1980s in the Netherlands (BTK, 2020). Cryptocurrencies officially took place in the markets after the real estate crisis in the United States in 2008. Bitcoin, the virtual currency system created by Satoshi Nakamoto (2008), attracted attention as a coin that is not printed by any central bank, government, or institution and secured with cryptographic protocols making it suitable for online shopping (Ron and Shamir, 2013). The bitcoin application consists of three parts as a miner, blockchain, and wallet. It is not dependent on the internet but can be transferred to another person when desired. In this application, the mining process secures and processes transactions to prevent double-spending, the blockchain updates itself every ten minutes like a bank and distributes information to wallets in the network, and the wallet keeps a copy of the Blockchain (Presthus and O'Malley, 2017). Blockchain has been identified as the critical technology behind cryptocurrencies (Arli et al., 2020).

In her first speech as President, the President of the European Central Bank (ECB), Christine Lagarde, stated that the bank has plans to direct its special task committee to digital currencies. Lagarde stated that with the developments in the digital money market, the European Central Bank should play a leading role in using new technologies that may preclude traditional banking systems and procedures (BTK, 2020).

Although investors, states, and international organizations have started showing interest in virtual currencies, the same level of interest in retail and direct consumer relations has not matured. Retailers are interested in adapting to crypto payments soon; however, a significant factor limiting crypto adoption by retailers is low consumer demand (Jonker, 2018). On the other hand, there is insufficient research on what blockchain and virtual currencies mean for consumers (Schlegel et al., 2018). A study conducted in 2016, 768 retailers operating in different fields in the Netherlands, their payment methods, perceptions, and intentions regarding online crypto payments were measured. According to the findings, virtual payments constitute $13 \%$ of the total retail trade (Jonker, 2019). Another study in Greece showed that 17-20\% of the participants used Bitcoin as a payment and investment method, while the remaining 65-70\% had negative thoughts and a defensive attitude towards virtual currency (Tsanidis et al., 2015). This research also determined that the Greek retail industry started to adopt the virtual Money application as a payment method, but consumers experienced a lack of knowledge and confidence in the system. Also, consumers had issues and doubts about the usefulness, time, and money-saving benefits of virtual currency use (Tsanidis et al., 2015). In Canada, research revealed that Bitcoin awareness was quite similar in all age groups, Bitcoin use was intensive among younger groups, and more educated Canadians were more likely to adopt payment technologies with Bitcoin. Researches show that $72 \%$ of people with $100,000 \$$ or higher annual income are more aware of Bitcoin than those with low income (Henry et al., 2018). In order to enhance usability and to build trust, the gap between Bitcoin Blockchain technology and user expectations needs to be narrowed (Alshamsi and Andras, 2019). According to studies, consumers care about the transfer fee and speed rather than the stability of the crypto Money used. Regarding intention to buy with crypto money, consumers are willing to buy products or services with cryptocurrencies due to advantages and conveniences such as the 
reduced risk of carrying money, the possibility of making faster and lower commission fee transfers, making transactions on national, international markets without using brokers. (Ciaian and Rajcaniova, 2016).

Internationally virtual currency use adoption level is low because of the negative perceptions on legal support, trust and experience. Trust can be formed faster when governments better regulate and ensure virtual currencies (Albayati et al., 2020). It is predicted that the legislation accepted in the Congress of the United States of America will play a vital role in shaping the future of virtual currencies (Lee et al., 2015). Germany has already allowed several cryptocurrencies to be exchanged between retailers and consumers (Arli et al., 2020). The literature survey shows that consumers still have reservations about quickly adapting to virtual money use in retailing and online shopping perception of trust regarding the use of virtual money in retailing and online shopping.

The primary purpose of this study is to search the customer behaviors and motives behind virtual money use decisions in retailing. In this study, the reasons why retail sectors add virtual currency payment options among traditional ones, how the capability of shopping with digital money affects the consumer decision-making process have been investigated. The problematics of this research include the reasons for retail businesses to switch to the cryptocurrency payment system, the benefits of this system to the consumers, the advantages of virtual money payments to retailing, the prospective perception of the status of virtual money, and the problems faced by the retailer and the consumers in the transactions of virtual money payments.

\section{THEORETICAL BACKGROUND}

\subsection{Cryptocurrency}

Cryptocurrency is a virtual currency that uses cryptography, in other words, encryption designed as a digital exchange against cash. Cryptoassets are decentralized, unlike centralized banking systems. This decentralized system is based on a blockchain that functions as a distributed ledger, the public transaction database of cryptocurrencies (Schuh and Shy, 2016). With the emergence of the current classical payment system's inability to fully meet the wishes and needs of the person and the loss of trust in real markets and central financial institutions as a result of the global economic crisis of 2008, Bitcoin and blockchain technology which Satoshi Nakamoto revealed began to be seen as an alternative to the existing financial system (Redshaw, 2017). Mining in cryptocurrency is virtual like itself. In other words, it has nothing to do with known mines. It is considered to have been discovered, not printed, and is likened to gold due to its limited number. Those who discover are also called miners. Cryptocurrency has no freedom in how much to supply. A certain amount is released every day to be discovered, and specially equipped computers carry out this process. In addition to high-equipped computers, highly-equipped personnel is also required, and the first to solve the transaction is given the right to earn crypto money. When these are offered to the market, the free use, buying and selling process begins (Güngör, 2021).

Today, it is known that there are more than 6000 cryptocurrencies, and some high-volume cryptocurrencies such as Bitcoin, Ethereum, Ripple, and Litecoin are used in trade in more than 60 countries (CoinMarketCap, 2021). These cryptocurrencies, which have acquired a high level of interest from investors for the last four years, have become the center of attention with the ongoing pandemic in 2020 and have multiplied their values. In addition, there are more than 17 thousand 
cryptocurrency ATMs in 68 countries worldwide, and their number is increasing day by day (Coin ATM Radar, 2021). Businesses are inclined to accept cryptocurrency payments in addition to traditional payment methods to attract the attention of new generation consumers and achieve positive results on sales and marketing efforts (Vora, 2015; Andrei et al., 2019). The increasing adoption and spread rates of digital currencies have become the priority policies of some states and their international organizations.

\subsection{Adoption and Diffusion of Innovations}

Blockchain technology started a new era in business and social life. According to stakeholders such as developers, entrepreneurs, and tech enthusiasts, blockchain technology has the power to reconfigure the economic, legal, political, and cultural landscape. Some skeptics assert that this new technology contains much uncertainty (Frizzo-Barker et al., 2020).

Making payments using cryptocurrencies is a technological innovation in the context of financial services. The adoption of technological innovations has been examined within the framework of different models in the literature. Among these models, the Diffusion of Innovation Theory (DIT) (Rogers, 1995) is one of the most frequently used theories. This theory was used in this research. Also, payment systems have been studied based on many models and theories, including the Technology Acceptance Model-TAM, Theory of Reasoned Action-TRA, Unified Theory of Acceptance and Use of Technology-UTAUT, Theory of Planned Behavior- TPB, Technology, Organization, and Environment Theory-TOE, and Task-Technology Fit Model-TFF. The adoption process of technology and innovations has been studied for more than 50 years (Sahin, 2006). "Diffusion of Innovations Theory" (Rogers, 1995) is the most widely used theory on the diffusion and adoption of technology.

According to Rogers (2003), adoption is the decision to "fully utilize an innovation as the best available course of action." As a result of this decision, the consumer, who has had a positive experience, will tend to repeat their behavior and share the benefits they have obtained with their surroundings. Diffusion is defined as "the process in which an innovation is transmitted between the social system members through certain channels" by Rogers (2003). The four main factors that affect the diffusion of innovations are innovation, communication channels, time, and social system. Currently, one of the biggest obstacles in the use of cryptocurrencies as a payment system is uncertainty. According to Rogers, uncertainty is the most crucial obstacle in the adoption of innovations. To reduce uncertainty, consumers should be aware of all system consequences and get information about the pros and cons of the system. A communication environment must be created to spread knowledge and experience (Rogers, 2003).

According to Rogers (2003), time is also an essential factor in the diffusion of innovations. Time indicates the period of adoption or rejection when the consumer notices the innovation. It is possible to categorize individuals according to their innovation and technology adoption behavior: Innovators, early adopters, early majority, late majority, and laggards (Fisher and Pry, 1971).

The social system is the last element in the diffusion process. Rogers defines the social system as "a set of interrelated units dealing with common problem-solving to achieve a common goal" (Rogers, 2003). The current social structure is shaped by the discourses of those who have adopted this system. At that particular moment, whichever communication source is more robust, that discourse becomes more effective. It seems that positive news is much more effective than negative news. Every individual wants awful news to be forgotten. In an environment where 
everything is digitalized, it is thought that money will also be digitalized. This idea creates a strong belief that cryptocurrencies will be the currency of the future.

According to the Diffusion of Innovations Theory, the innovation-decision process is defined as "an information seeking and processing activity in which the individual is motivated to reduce uncertainty regarding the pros and cons of an innovation." The innovation-decision process is described in five steps, as shown in Figure-1 below (Rogers, 2003).

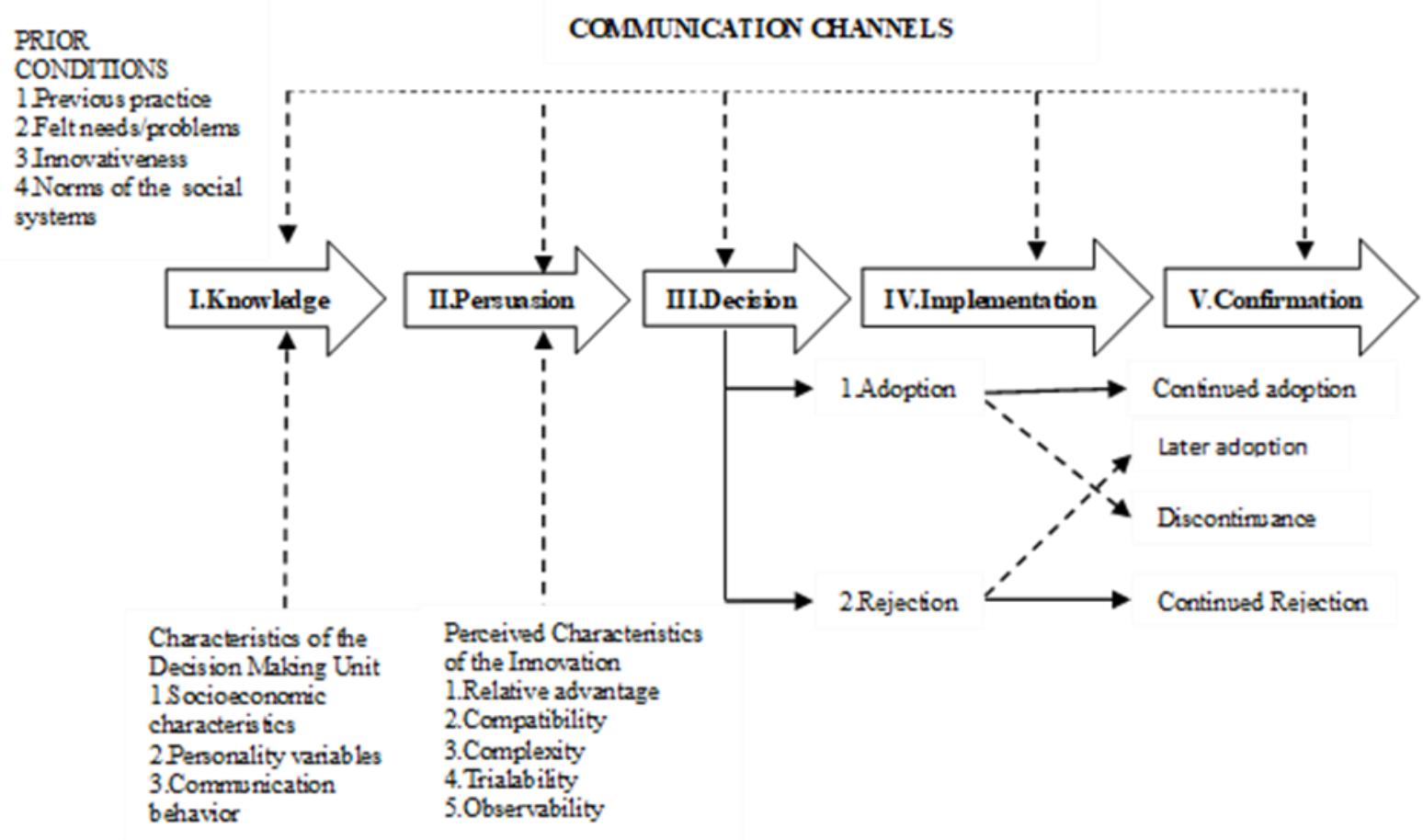

Figure 1: A Model of Five Stages in the Innovation-Decision Process

Source: Diffusion of Innovations, Third Edition by Everett M. Rogers, 1983, Pg-165

At the first stage of the innovation-decision process, the individual gets information about innovation and its functions. By evaluating the advantages and disadvantages of innovation for themselves, they shape their attitude towards it at the persuasion stage. Then, the individual obtains additional information at the next stage and decides to accept or reject the innovation. At this stage, the individual is mainly affected by the evaluations of the others around them. The implementation stage takes place when the decision is made to adopt innovation. In the last stage, the individual confirms and strengthens their adoption decision.

Innovative consumers are more willing to try and purchase new products and services than other consumers (Midgley and Dowling, 1978; Roehrich, 2004). They also effectively promote the products they tried to other consumers, thus playing a critical role in consumption behavior.

\subsection{Empirical Literature}

The value of the crypto money market is gradually increasing. As of 2021, the total value of the crypto money market reached 1,5 Trillion \$ while the market value of Bitcoin exceeded 1 
Trillion \$ in March 2021.(CoinMarketCap, 2021). Silbert, the founder of Bitcoin Investment Trust, explains the Bitcoin adoption process as a 5- stage process. These stages are called Experimentation, Early Adopters, Venture Capital, Wall Street, and Global Consumer Adoption phases. In the Wall Street phase, corporate investors and banks show more interest in Bitcoin and consider using it in retail (Bambrough, 2021). In the last phase, the purchase, possession, and spending of Bitcoin should be quite easy. Customer demand to use Bitcoin in retailing may contribute faster adoption process (Mauldin, 2014).

The factors affecting the intention to use are"performance expectancy" related to the cryptocurrency and "effort expectancy" regarding the user and the system (Silinskyte, 2014). Besides, the facilitating conditions also affect Bitcoin use intentions. Perceived ease of use, perceived usefulness, and perceived trustworthiness factors have a positive effect on the intention to use cryptocurrency (Shahzad et al., 2018). The legal inspection and guarantee/insurance applications and the customers' personal experiences positively affect the intention to use cryptocurrency applications. The higher the level of trust, the faster technology adoption (Albayati et al., 2020). Investigating the use of Bitcoin as a payment and investment tool and comparing it with credit cards and debit cards, Alshamsi and Andras (2019) reported that customers find credit/debit cards more valuable than Bitcoin. Their research also reveals that Bitcoin carries security concerns, and users should have information about the system's operation, security, and usage (Alshamsi and Andras, 2019).

Bitcoin users are curious investors, which is one of the factors driving them to use Bitcoin (Presthus and O'Malley, 2017). The size of businesses and economic uncertainties can also affect the use of cryptocurrency. New businesses, small-sized businesses, and businesses in developing countries with a higher level of uncertainty in their economy accept cryptocurrency payments in a greater ratio than others (Polasik et al., 2015). Higher-level awareness increases the use of cryptocurrency in retailing (Jonker, 2019). In the USA, most customers bought crypto money expecting a value increase in the future, meaning the rate of cryptocurrency adoption was very low other than making investments (Schuh and Shy, 2016).

Research in Canada revealed that the Bitcoin usage level in online shopping is deficient. University graduates tend to use Bitcoin more compared to other groups. The "curiosity about new technologies is anticipated as a motivator for Bitcoin usage by younger generations (Henry et al., 2018). Some authors argue that cryptocurrency use for small transactions is not practical with current technology (Erdin et al., 2020). As soon as different products, services, and models to be developed to enhance the ease of cryptocurrency use in shopping, the adoption level will increase exponentially due to the network effect (Schlegel et al., 2018).

Cryptocurrency uses blockchain technology, enabling retailers to effectively store information about their suppliers, execute payments/contracts flawlessly, and check product reliability. In addition, it is possible to develop safe and effective solutions for coupons, loyal customer applications, and discounts with this system. Coupons, loyal customer practices, and discounts are important issues and have a wide range of applications in retailing (Medida, 2020). Blockchain technology can fundamentally change the entire retail shopping experience (Klaus, $\mathrm{P}$. and Zaichkowsky, 2021). Today, Amazon Go and Fresh constitute examples of innovative retailing; however, these automation-based systems exclude the consumer's emotions (Klaus and Kuppelwieser, 2020). 


\section{METHOD}

The primary purpose of this study was to investigate the consumer behaviors on cryptocurrency use in retailing from sellers' point of view. This research examines the profiles and purchasing behaviors of retailers and consumers who shop with cryptocurrency in Turkey. This research seeks answers to the questions below;

* Why do retailers and consumers prefer to exchange with crypto-money?* Which goods and services are preferred to be exchanged with crypto-money?

* What factors satisfy or dissatisfy the retailers and consumers from shopping by using cryptocurrency?

* What are the main factors that may compel retailers to conduct their payments with cryptocurrency?".

The main subject of this research is to examine the customer experiences and observe the retailers accepting cryptocurrency payments.

\subsection{Research Design}

In this study, a qualitative approach was implemented (Priporas and Mylona, 2008) with an exploratory (Creswell, 2014) and interpretive point of view (Gray, 2013). NVivo 11 Program was used in this research. The theoretical framework of the study was formed on Rogers's Theory of Diffusion of Innovation. According to the theory presented by Rogers (1995), an idea, practice, or an object perceived as new in individual and organizational approach is defined as innovation (Rogers, 1995). According to the theory, innovation adoption consists of a five-stage process depending on accepting or not accepting the decision (Rogers, 1995). Each stage of this process makes the final decision by reducing uncertainty regarding innovation and advancing (Rogers, 2003). In this context, 45-minute interviews were conducted with participating companies over the Zoom Video-conference application program to understand the customer experiences of retailers using cryptocurrency. The findings obtained were analyzed in the context of Rogers's Theory of Diffusion of Innovation.

\subsection{Data Collection and Analysis}

The meeting request e-mails were sent to 79 enterprises (Coin-Turk Report Business List, 2021) from different sectors which accept cryptocurrency payments. In the first week, five businesses responded to e-mails and accepted participating at the online meeting. Next week four more businesses agreed to join the meeting. In order to increase this number, based on the news on cryptocurrency use in retailing, 40 more businesses in Europe and USA that accept cryptocurrency payments have been contacted via e-mail. We could not get any affirmative responses from foreign companies. The nine companies that accepted the interview were informed that the interviews would be conducted via the Zoom program. They consented to record the interview data so that the interview data could be analyzed descriptively. 45-minute interviews were held with nine company officials who answered all questions between February 25th, 2021, and February 28th, 2021.

The findings of the study were obtained from the interview data conducted through video conference. Each interview lasted 45 minutes, and the video and audio recordings in the videoconference program were transcribed into text. While the answers given to the interviews' questions constituted the study's qualitative data, the types of the sectors constituted the quantitative part. 
Volkan TEMizKAN, M. Ali YETGíN \& Kasım YILMAZ, 2022, Cilt: 23, Sayı: 1, ss. 25-48.

This study analyzed the retailers' thoughts on who accepted crypto payments within Rogers's Theory of Diffusion of Innovation.

\subsection{Sample Profile}

According to The World Economic Forum Report (2021), Turkey is ranked 4th in the world and first in Europe in cryptocurrency usage level. A total of 79 businesses in Turkey that accept payments by cryptocurrency constitute the research population. The sample comprises nine retail companies which accept participating in the interview (Table 1). The companies that participated in this research have switched to cryptocurrency payment applications for different reasons.

Table 1: Profiles and Overview of Respondents

\begin{tabular}{|c|c|c|c|c|c|c|}
\hline Respondents & Age & Gender & Education & $\begin{array}{l}\text { Frequency of } \\
\text { receiving payments } \\
\text { with } \\
\text { cryptocurrency }\end{array}$ & $\begin{array}{l}\text { Inter est } \\
\text { towar ds new } \\
\text { technology }\end{array}$ & Sector \\
\hline $\mathrm{T} 1$ & 43 & $\mathrm{M}$ & $\mathrm{BA}$ & $4-5$ per y ear & Good & $\begin{array}{l}\text { Tourism and } \\
\text { travel services }\end{array}$ \\
\hline $\mathrm{P} 1$ & 56 & $\mathrm{M}$ & MSc & 3-4 per year & Excellent & Printing press \\
\hline I1 & 40 & $\mathrm{M}$ & $\mathrm{BSc}$ & 2-3 per year & Excellent & $\begin{array}{l}\text { Information } \\
\text { technologies }\end{array}$ \\
\hline G1 & 36 & $\mathrm{~F}$ & $\mathrm{PhD}$ & 2-3 per year & Excellent & $\begin{array}{l}\text { Graphic } \\
\text { design }\end{array}$ \\
\hline R1 & 51 & $\mathrm{~F}$ & $\begin{array}{l}\text { High } \\
\text { school }\end{array}$ & Once a year & Good & $\begin{array}{lr}\text { Real } & \text { estate } \\
\text { sales } & \text { and } \\
\text { rental } & \\
\end{array}$ \\
\hline E1 & 58 & $\mathrm{M}$ & MA & Once a year & Excellent & Education \\
\hline $\mathrm{I} 2$ & 29 & $\mathrm{M}$ & MSc & Once in three years & Excellent & $\begin{array}{l}\text { Information } \\
\text { technologies }\end{array}$ \\
\hline $\mathrm{C} 1$ & 34 & $\mathrm{M}$ & $\begin{array}{l}\text { High } \\
\text { school }\end{array}$ & $\begin{array}{l}\text { No payment with } \\
\text { crypto }\end{array}$ & Excellent & Rent a car \\
\hline $\mathrm{O} 1$ & 52 & $\mathrm{M}$ & $\mathrm{MSc}$ & $\begin{array}{l}\text { No payment with } \\
\text { crypto }\end{array}$ & Excellent & E-Commerce \\
\hline
\end{tabular}

\section{FINDINGS}

\subsection{The Knowledge Stage}

The knowledge stage comprises learning activities about innovation. What, why, and how" questions are asked to figure out the originality and functions of the innovation. In this study, the businesses interviewed shared their experiences about their motivations and consumers' knowledge levels and awareness about cryptocurrency use in retailing.

According to Rogers (2003), at this stage, awareness, how-to knowledge, principles are the main components of the information gathering. How-to knowledge is fundamental in complex technological innovations. It is also necessary to understand the reasons why an innovation emerged (Sahin, 2006).

T1 explained: "Generally, consumers who already have crypto money accounts for investment purposes prefer shopping with cryptocurrency when they learn we accept the crypto payment option. Especially our overseas customers prefer shopping from us to refrain from 
complex banking transactions and high commissions. Consumers choose to pay with cryptocurrency when they think doing so is advantageous. If the bitcoin price is fluctuating, they prefer other payment options."

P1 said. "I think crypto coins will become legally designed and protected in the future. Now people can buy bitcoin easily. For now, it is an investment tool, but probably that will change. We have made transactions using Bitcoin four times at our company, and we have not had any problem. Not many people are aware of that payment option. In this system, transferring coins to the wrong address would be a disaster because it is irreversible. Nevertheless, we have not had such a bad experience until now."

I1 supported: "It is very advantageous in online shopping, rental payment, and transferring money. Like a bank in pocket, open 24/7. It renders complete control. Please compare the fees received from bank accounts, credit cards, and transaction fees with those charged using crypto. I think negative perceptions will disappear if states embrace cryptocurrency and make regulations in the long run. Digital currencies will become more widespread with government assurances. Since everything will be digitally recorded, tax control will be easier. I think it will be the safest payment and transfer tool in the future."

Interview participants' implications overlap with the study results carried out by Jonker (2019), who states that higher-level awareness increases the use of cryptocurrency in retailing. The consumer must first be aware of the existence of cryptocurrencies. If the information they acquire contains negativity, they will probably be biased against cryptocurrencies. The individuals having prejudice because of the unfavorable information will develop negative attitudes and behaviors. Then they may choose to wait until the adoption of cryptocurrency used by the vast majority of society. In the early days of Facebook's emergence, most people hesitated to use their real name and surname there, but today people willingly share their date of birth, much private information, and moments from their daily lives. For complex innovations to be adopted, the individuals must also have sufficient "how-to" knowledge. Internet banking and later on mobile banking used to be complicated; however, nowadays, even stock exchange transactions can be handled quickly via mobile application. In some cases, an individual may have all the necessary knowledge about cryptocurrencies, but that does not guarantee that individual will adopt innovation because the personal characteristics and attitudes may also shape the adoption or rejection of innovation.

\subsection{The Persuasion Stage}

The persuasion stage takes place when a person develops a positive or negative attitude towards innovation. However, the positive or negative attitude does not necessarily lead to accepting or rejecting the innovation (Rogers, 2003). The knowledge stage is known to be cognitive, and the persuasion stage is known to be emotional. Uncertainties regarding the functions of innovation and social, environmental evaluations affect the ideas and beliefs of individuals regarding innovations. Subjective evaluations of close friends are more valuable for individuals (Sherry, 1997).

G1 specified: "Cryptocurrencies are mostly considered as an investment tool by consumers. They want to refrain from the effects of inflation with their savings. Bitcoin became more popular in 2021. The announcement of many corporate investors that they will include cryptocurrencies in their portfolio persuaded people about reliability. While some tycoons made positive statements about cryptocurrency, some others did the opposite. However, I think even that contributes to the awareness level. Advertising is useful, either good or bad, right? Every news 
Volkan TEMizKAN, M. Ali YETGíN \& Kasım YILMAZ, 2022, Cilt: 23, Sayı: 1, ss. 25-48.

that comes out makes people even more curious. People who wonder are investigating. If they see that it offers convenience and benefits, they want to try it.

Some ask questions when they see the bitcoin payment emblem on our website. We provide the necessary information. Maybe they will not use this payment method right now, but they will get familiar with the system. Their courage to try will increase as they frequently come across such a system. Every positive experience will grow as it is shared."

I2 stated: "The world is changing at an impressive rate. I think it is time for the traditional monetary system to change. Bitcoin is leading a big transformation here. I think this transformation will improve the financial system. The easiest way to buy and sell is to use exchanges. I have only a few customers shopping with Bitcoin, but I believe that the crypto payment method will be used widely in the future. Because I know that more than 1 million Bitcoin accounts opened in 2021 in Turkey”.

The social system affects the individual adoption decision process. Participant business owners state that positive announcements from famous investors worldwide increase individuals' trust towards cryptocurrency. The results of the study support this assertion carried out by Al Bayati et al. (2020), which reveal that higher trust levels ease technology adoption.

Although Bitcoin is not yet positioned at the center of payment tools and systems, it can be perceived as a threat to the functionality of banks, with its system operating independently of any bank. It has a competitive advantage in the field of fund transfers at the global level. In addition to being used as a payment tool, Bitcoin also functions as an essential investment tool. Since its emergence, Bitcoin has earned its investors a lot despite its rapid fluctuations causing appreciation and loss. According to some authors, most Bitcoin buyers only buy it for investment, not for spending. Rapid value change is one of the perceived risks (Tu and Meredith, 2015).

\subsection{The Decision Stage}

In the Decision Stage, the individual chooses to adopt or reject the innovation. While the adoption decision describes the full use of an innovation, rejection means not adopting the innovation. (Rogers, 2003). The possibility of partial testing of innovation accelerates its adoption. At every stage of the Innovation-Decision process, rejection may be encountered. Two types of rejection can be mentioned, which are active and passive rejections. Active rejection means that the individual is trying the innovation but not adopting it due to his/her experience. In passive rejection, the individual does not even consider adopting

innovation. Group adoption of innovation can affect and change decisions into common adoption types, especially in eastern cultures.

R1 stated: "It is necessary to keep up with the digital world. Cryptocurrencies offer both payment and investment opportunities, just like digital gold. After all, it gains more value than the country's currency. It offers some advantages such as low transfer costs, time savings. In particular, it enables us to receive payments from our foreign customers without extra charges. I can see the spread and adoption of bitcoin gradually, so if you want to take part in the global market, you should use these payment methods. How much paper money are we using now? Or what percentages of customers pay in cash? Maybe paper money will not disappear, but I think cryptocurrencies will change financial tools."

O1 stated: "Payment with Bitcoin enables customers to finish their transactions in one attempt and action instead of paying commissions to brokers back and forth to transfer his currency 
to sellers' national currency. Crypto money payment method is swift, has low cost, and is secure. Currently, I have very few customers who know how to use cryptocurrency, and I have not received payments this way yet. However, I already started to advertise that I accept payments with Bitcoin, and I registered my company as such. I feel it is necessary to offer different payment methods to customers."

Roussou and Stiakakis (2016) found out that some people preferred to use bitcoin because of their technological curiosity. However, in that study, many participants stated that they decided to wait for others to use cryptocurrency and see the results first. In many studies, freedom and distrust in the banking system are the main factors that encourage or motivate people to use Bitcoin. The obstacles that cause people to hesitate to use Bitcoin appear as lack of information, fear, anxiety against the uncertainty, lack of infrastructure, and problems experienced in the bitcoin network (Presthus and O'Malley, 2017).

\subsection{The Implementation Stage}

During the implementation phase, and innovation starts to be implemented. At this stage, there is still some degree of uncertainty in the diffusion of the innovation process. This uncertainty is mainly about the consequences of using innovation. Therefore, the user may need the help and support of change agents to avoid the effects of uncertainties. If the "new idea identity" disappears for any reason, the innovation-decision process may end. (Rogers, 2003).

E1 stated: "I see that there is a risk transferring funds to a wrong account in this system and the transaction is irreversible. However, as in real life, you must secure your wallet. You can pay shopping with Bitcoin worldwide easily, and you have control of your own money. Of course, such important features come with important security concerns. Bitcoin can be very safe if use correctly."

C1stated: "We have seen a growing interest in cryptocurrencies all over the world. This situation caught our attention, and we started to investigate. Later, we saw companies that accept payments with cryptocurrency in the leasing sector, and we wanted to share this opportunity with consumers. We want to be one of the first companies implementing this system in Turkey when people will start using it more frequently in the future. Turkey has the youngest population in Europe, and they are incredibly curious about technology. In our industry, we saw what technology could do with UBER. Therefore, we know that when customers are offered convenience, they can adapt immediately, and we think this payment method offers convenience. The point that should not be ignored is that bitcoin loses its advantage in low amounts payments. However, for transfers over 300-500 \$, it saves time and the transfer cost. I think our customers will prefer it because we receive many payments in this range."

Central authorities (banks, notaries, land registry offices.) perform registration and authentication because this verification service is required for legal proof. Therefore, there is a need for central systems to verify the official transactions, and those central systems receive commissions for verification and confirmation services. If something happens to the central authority, delays, losses, thefts, slowdowns, and corruption may occur in these human-based systems. In addition, many people may need to work here. Any transaction between A and B person, whether sending money, buying, selling real estate, or buying a car, can be handled by smart contracts written on the blockchain. The same information can be downloaded to multiple computers at the same time. All transactions that require verification can be performed with smart 
Volkan TEMizKAN, M. Ali YETGíN \& Kasım YILMAZ, 2022, Cilt: 23, Sayı: 1, ss. 25-48.

contracts written on the blockchain system. By using blockchain technology, transactions can be performed faster, securely, and cheaply.

\subsection{The Confirmation Stage}

It is the phase of seeking support for the user's decision. According to Rogers, if individuals are exposed to confusing messages about innovation, they can change their adoption decisions. However, they are more prone to messages that support their decisions at this stage. There may also be adoption denial at this stage. Denial can occur in two ways as follows. First, the person may abandon the adoption decision because of a better substitution. In the second, the individuals undergo adoption denial because they are not satisfied with the performance of the innovation. The second is called "disappointment denial."

T1 stated: "I anticipate acceptance of Bitcoin payments as an opportunity for advertising and customer satisfaction. Especially in competitive sectors like ours, businesses with different customers should offer their customers every possible convenience and option. I thought that by accepting payments with Bitcoin, I would create awareness and attract these customers simultaneously. It was very new back then, and people did not even know what it was, but now more and more people do. We are very pleased with the interest they are showing currently. Because cryptocurrencies have always been a field, I believed in and trusted. Also, I have invested in this field. It gives me more hope for the next level."

E1 stated: "Since Bitcoin is not processed through the traditional banking system, nobody charges you due to your cryptocurrency. However, cryptocurrency can not offer opportunities as much as a credit card, just like giving credit or allowing partial payments. Turkey has a young population and is one of the top 5 countries with the most registered cryptocurrency trading platform. This is proof that Generation $Z$ is adopting digital currencies more quickly. In this respect, Ifind generation $Z$ much more practical than us. Therefore, something being digital is not a problem for the $Z$ generation. "

As the demand for Bitcoin increases, it becomes more expensive to be used. Bitcoin was once seen as an alternative to providing banking services where banking was not available. Now, bitcoin is purchased for investment purposes, and expectations have increased its value. Less than $30 \%$ of bitcoin is currently used for payment for goods and services. Hedge funds and corporate investors are also effective in their increasing demand. Bitcoin mining is known to consume high energy and is not environmentally friendly, but the critical point here is that other cryptocurrencies that allow fast and low-cost transfers without mining can be used with blockchain technology. With this kind of digital currency, it is now possible to make the payment in under a second. In particular, the adoption of cryptocurrencies by Generation $\mathrm{Y}$ will trigger mass transitions. This promises to replace cash and credit cards. The network effect will become an exchange tool that will express value with everyone knowing and telling each other. If digital money is to be used, transactions should be made quickly and instantly; this will positively affect the experience of using crypto money in shopping. Figure 2 shows the main factors that affect the customer experience in cryptocurrency use.

Although regulators are trying to make legal regulations for cryptocurrencies, the increasing use of blockchain will pave the way for cryptocurrencies. From now on, states will compete to invest in this field. The proof of this is that the market value of the stable coin Tether (USDT), which is now the leader, has exceeded \$ 39 Billion. Although the use of cryptocurrencies as a 
payment method is early for now, more people will have crypto money, price fluctuations will disappear, and people will start trusting cryptocurrencies.

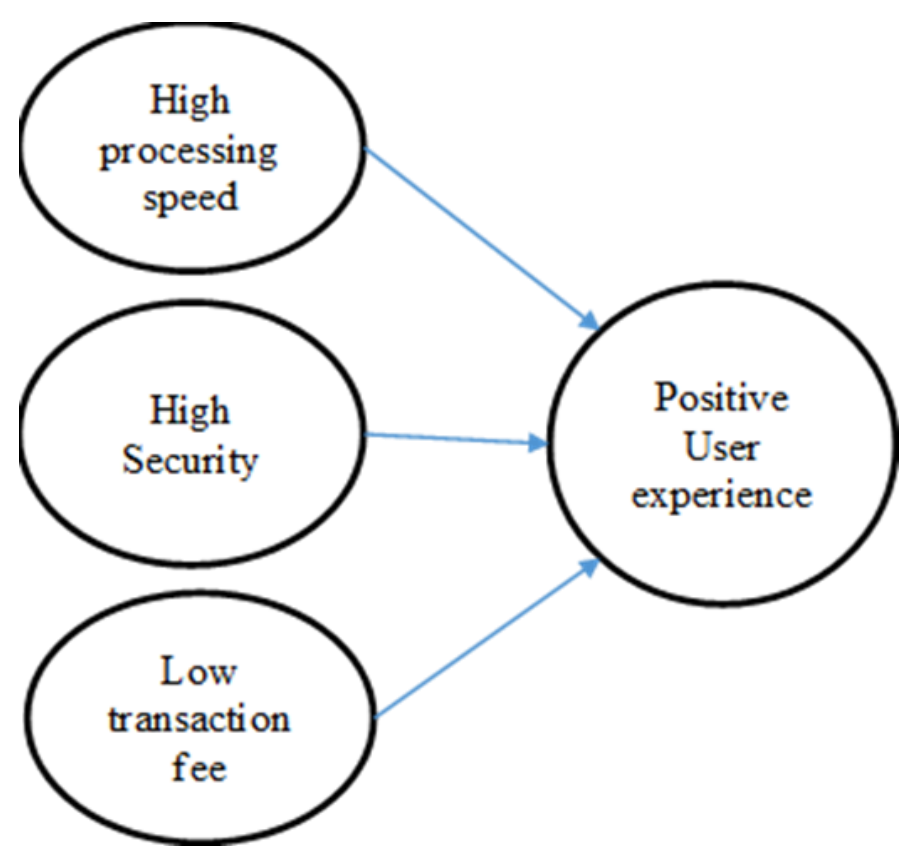

Figure 2: Services that cryptocurrencies should offer for a positive user experience. (The research model was created according to content analysis results obtained from the interviews with the NVivo program).

The model developed in Figure 2 was developed based on the results of the interviews. Critical points that affect customer satisfaction have been identified in the statements of businesses using bitcoin as a payment method. These points are that crypto money payment methods have low transaction fees, high reliability, and high transaction speed. These features of crypto payment methods, which lead to customer satisfaction, have led to a positive user experience. As a result of the literature review, the most critical factors affecting the user experience are; time and cost savings and ease of use. In addition, in the rapid spread of innovations, the innovation in question must provide benefits. Since crypto money payment methods meet these conditions, it is predicted to be adopted quickly in the future. Based on this prediction, the model in Figure 2 was developed by the authors.

\section{DISCUSSION}

\subsection{Theoretical Implications}

The innovation-decision process begins with the acquisition of information about innovation, as presented in Figure 1. According to the individual's positive and negative attitudes formed at the persuasion stage, acceptance or rejection about the innovation is achieved. Adoption or rejection decisions may or may not be strengthened during the final confirmation stage (Rogers, 2003). Although the emergence of cryptocurrencies dates back to 2009 (Nakamoto, 2008), it is still an innovation that has not completed its diffusion process. According to Rogers (2003), time is an 
essential factor in the diffusion process of innovations. During the adoption process, new problems may emerge and may affect decisions. Rogers (2003) classifies individuals according to their degrees of adoption level of innovation into five categories as; innovators, early adopters, early majority, late majority, and laggards. The important thing in early adaptation is the time between the individual's learning and his permanent adaptation to the innovation.

According to the findings, those who use cryptocurrencies as payment tools are few and compose the 'innovators group'. Presthus and O'Malley, (2017)'s findings on the subject are also similar to this result. Those who use cryptocurrencies as investment tools constitute the "Early Adopters" consumer group classified in the "Diffusion of Innovations Theory," and their number is much higher than the innovator's group. This result shows that consumer groups who prefer to use cryptocurrencies as payment methods are at "the persuasion stage," but those who use digital money only as an investment tool are still at "the knowledge stage" of adapting to an innovation process.

Not a day goes by without surprising, and sometimes confusing positive or negative news comes out in the world. This news causes a lot of discussion and speculation. The discussions are essential to make progress by exploring and solving problems (White et al., 2020). However, uncertainty about the financial risks of cryptocurrencies makes the trust factor a priority (Yoo et al., 2020). Establishing trust requires official authorities to act and step forward to make regulations (Wonglimpiyarat, 2016). According to the interviews done in this study, the trust element and official engagement will be the most influential factors affecting consumers' decisions about cryptocurrencies. Most countries intend to issue their digital currency.

\subsection{Practical Implications}

In the past, when credit card usage was first introduced as an alternative to cash, its acceptance and spread were slow. However, it was preferred due to its ease of installments, not cash, and rapid integration into the banking system. In addition, the opportunity provided to spend and use the credit card globally has facilitated its rapid spread. Since the credit card increased the consumer's expenditures, it also increased the total consumption volume with demand. Like credit cards, Bitcoin payment services should integrate more with existing payment systems so that the shopping experiences can be easier as credit card payments. Those applications may allow consumers to pay with Bitcoin on e-commerce sites or at POS machines.

Payments with Bitcoin provide benefits for consumers because of much lower commission rates. Also, crypto coins are accepted as an investment tool, new technology, or evolution of credit cards for some people.

Most people create cryptocurrency accounts for investment purposes. The retailer's acceptance of the cryptocurrency payment encourages customers' preferences about cryptocurrency use at their shopping. The increase of investors and sellers who prefer payments with cryptocurrency will make the use of crypto widespread in the retailing sector. Customers prefer cryptocurrency payment methods when they know it is advantageous.

Lack of government assurance or endorsement on cryptocurrencies causes doubts among ordinary people against digital coin use. Also, the possibility of transferring funds to the wrong address might have serious consequences. Once sent, the transfer is not retrievable. These insecurities must be overcome for people to use cryptocurrencies with a piece of mind. 
Retailers and consumers think using cryptocurrency for online shopping, rental payments, and fund transfer has advantages. Retailers may continue having payments without interruption on $7 / 24$. Governments may have advantages with taxation since every transaction is digitally recorded. Consumers may benefit from low transaction fees.

People get more familiar with cryptocurrencies lately because they continuously hear many positive or negative news about them. When they learn a billionaire businessman plans to invest in digital coins, people become more curious, and their doubts decrease. Any type of advertisement contributes to awareness. Technological curiosity also enhances the chances of cryptocurrency use in retailing.

Even though there is a risk investing in Bitcoin because of the possible price fluctuations, people continue opening new accounts to make investments. Cryptocurrencies have the potential competitive advantages in fund transferring and investment. The business owners participating in this research have adopted the payments with cryptocurrency for different reasons. Sellers think the money is already digital at the moment, just like cryptocurrency. They believe crypto money use in retailing is not odd at all. E-commerce store owners want to offer users as many payment options as possible. The sellers are better protected against retail fraud because of canceled transactions at cryptocurrency payment methods.

Crypto money transactions can be made anonymously. People who care about their privacy may consider using cryptocurrency professionally. Buyers with an exceptionally high understanding of cyber security often prefer anonymous transactions. As a result, cryptocurrencies have a high potential to be used for cheap, fast, and global payment transactions.

However, cryptocurrency use has downsides related to daily use and security issues. Paying in cryptocurrencies is not practical for small purchases, such as buying a coffee. It is costly and takes a longer time. Some of the newly released cryptocurrencies claim to have solved this problem completely. Many users are also concerned about security threats. Particularly, hackers may pose a severe security threat.

Prices vary widely in the cryptocurrency market. Market values may rise and fall within a few hours. In this case, the business gains when the prices of cryptocurrencies rise and loses when they fall. If the market is volatile, sellers will not prioritize cryptocurrency. Nevertheless, cryptocurrencies indexed to dollars or gold can offer a solution to this problem. 
Volkan TEMizKAN, M. Ali YETGíN \& Kasım YILMAZ, 2022, Cilt: 23, Sayı: 1, ss. 25-48.

\section{CONCLUSION}

The significant findings of this study include the following:

- The fact that businesses offer their international customers the option to pay with digital currencies enables them to perform faster money transfers at a lower cost.

- Business owners and consumers believe that more governmental regulations should intervene with digital currency usage. Because the common desire of buyers and sellers is a reliable and internationally recognized digital currency which facilitates trade.

- Generations $\mathrm{Y}$ and $\mathrm{Z}$, in particular, have adopted digital currency very fast. These generations like to use a common currency with international validity that they can use everywhere. They like to make the purchase quickly and practically without any obstacles.

- The fact that businesses offer different payment methods increases customer satisfaction. In particular, receiving payments with cryptocurrencies attracts the attention of consumers. For this reason, it is a good advertising tool as it increases the recognition of the businesses. Also, it inspires and supports an innovative and technology-driven business image on customers.

- There are many customers using cryptocurrency for investment. They may want to use cryptocurrency for shopping too. Businesses that accept cryptocurrency payments are the ones that can answer the needs of those customers. This payment option and capability increase customer satisfaction.

This study primarily contributes to the literature in two ways. First in-depth interviews with pioneer business managers who accept cryptocurrency at national and international trade enabled researchers to offer a model about cryptocurrency use motivation (Figure 2). As a result of this research, cryptocurrency using technology must meet three requirements to be an accustomed payment method. These requirements are; High transaction speed, high transaction security, and low transfer fee. This model is the first in the literature which depicts the features of cryptocurrency usage at national and international shopping applications by examining the sellers' and customers' shopping experiences.

Secondly, this study explores the experiences of the retailers accepting cryptocurrency for their business transactions with an in-depth interview method. This method allows researchers to obtain more detailed information about retailers' experiences, including their emotions, expressions, and perspectives that are otherwise very difficult to be explored. Thus, this study will contribute to future empirical studies on this subject. 


\section{LIMITATIONS AND FUTURE RESEARCH}

This study aims to explore consumer behaviors about cryptocurrency use in retailing. Interviews targeted the Turkish companies accepting cryptocurrency as a payment method in retailing. Therefore, it is an original study in terms of a significant attempt to understand seller and customer sensitivity towards cryptocurrency use in the retail market in Turkey. As the universe includes businesses accepting retail payments with cryptocurrency solely in Turkey, and the sample contains nine businesses that participated in interviews, this may be accepted as the study's main limitation.

Cryptocurrencies may be integrated into credit cards in the future. This integration will provide retail customers with many advantages. The effects of this possibility on the retail consumer experience can be investigated in future studies. Also, stable coins are being produced in more environmentally friendly ways. The acceptability of stable coins can be investigated in the future with the same method. A scale appropriate to the research model created by the authors may be developed later. 
Volkan TEMizKAN, M. Ali YETGíN \& Kasım YILMAZ, 2022, Cilt: 23, Sayı: 1, ss. 25-48.

\section{REFERENCES}

Albayati, H., Kim, S. K. \& Rho, J. J. (2020). Accepting Financial Transactions Using Blockchain Technology and Cryptocurrency: A Customer Perspective Approach, Technology in Society, 62, 101320. https://doi.org/10.1016/j.techsoc.2020.101320.

Alshamsi, A. \& Andras, P. (2019). User Perception of Bitcoin Usability and Security Across Novice Users, International Journal of Human-Computer Studies, 126, 94-110. https://doi.org/10.1016/j.ijhcs.2019.02.004.

Andrei O. J. Kwok \& Sharon G. M. Koh (2019). Is Blockchain Technology a Watershed for Tourism Development?. Current Issues in Tourism, 22(20), 2447-2452. https://doi.org/10.1080/13683500.2018.1513460.

Arli, D., Van Esch, P., Bakpayev, M. \& Laurence, A. (2020). Do Consumers Really Trust Cryptocurrencies?. Marketing Intelligence \& Planning 39(1). 74-90. https://doi.org/10.1108/MIP-01-2020-0036.

Bilgi Teknolojileri ve İletişim Kurumu (2020). Kripto Para Araştırma Raporu, Sektörel Araştırma ve Geliştirme Dairesi. https://www.btk.gov.tr

Bambrough B., (2021). As Bitcoin Suddenly Surges Over \$50,000, The Price of These $\begin{array}{llll}\text { Cryptocurrency Stocks Is Soaring. } & \text { S }\end{array}$ https://www.forbes.com/sites/billybambrough/?sh=f62cf496a896

Henry, C. S., Huynh, K. P. \& Nicholls, G. (2018). Bitcoin Awareness and Usage in Canada. Journal of Digital Banking, 2(4), 311-337.

Ciaian, P. \& Rajcaniova, M. (2016). The Digital Agenda of Virtual Currencies: Can BitCoin Become a Global Currency?. Information Systems and e-Business Management, 14(4), 883919.

Coin ATM Radar (2021). Find Where to Buy or Sell Bitcoins and Other Cryptocurrencies for Cash. Crypto ATMs. https://coinatmradar.com/

CoinMarketCap, (2021). Today's Cryptocurrency Prices by Market Cap. https://coinmarketcap.com/

CoinTurk Report Business List (2021). Businesses Accepting Bitcoin in Turkey. https://cointurk.com/bitcoin-kabul-eden-isletmeler.

Creswell, J. W. (2014). Research Design. Qualitative, Quantitative, and Mixed Methods Approaches Thousand Oaks (3 Edition). Sage Publications.

Erdin, E., Cebe, M., Akkaya, K., Solak, S., Bulut, E. \& Uluagac, S. (2020). A Bitcoin Payment Network with Reduced Transaction Fees and Confirmation Times. Computer Networks, 172, 107098. https://doi.org/10.1016/j.comnet.2020.107098

Fisher, J. C. \& Pry, R. H. (1971). A Simple Substitution Model of Technological Change. Technological Forecasting and Social Change, 3, 75-88.

Frizzo-Barker, J., Chow-White, P. A., Adams, P. R., Mentanko, J., Ha, D. \& Green, S. (2020). Blockchain as a Disruptive Technology for Business: A systematic review. International $\begin{array}{llll}\text { Journal of Information } & \text { Management, } & 51, & \end{array}$ https://doi.org/10.1016/j.ijinfomgt.2019.10.014 
Gray, D. E. (2013). Doing Research in The Real World (3 Edition). Sage Publications.

Güngör, K. (2021). Kripto/Dijital Para Ne Kadar Güvenli. Göller Bölgesi Aylık Ekonomi ve Kültür Dergisi Ayrıntı Dergisi, 8(97).

Henry, C. S., Huynh, K. P. \& Nicholls, G. (2018). Bitcoin Awareness and Usage in Canada. Journal of Digital Banking, 2(4), 311-337.

Jonker, N. (2018). What Drives Bitcoin Adoption by Retailers. De Nederlandsche Bank Working Paper, 585, 1-33. https://ssrn.com/abstract=3134404

Jonker, N. (2019). What Drives the Adoption of Crypto-Payments by Online Retailers?. Electronic $\begin{array}{llll}\text { Commerce Research and } & \text { Aplications, }\end{array}$ https://doi.org/10.1016/j.elerap.2019.100848

Klaus, P. \& Kuppelwieser, V. (2020). Guiding Directions and Propositions: Placing Dynamics at the Heart of Customer Experience (CX) Research. Journal of Retailing and Consumer Services, 59, 102429. https://doi.org/10.1016/j.jretconser.2020.102429

Klaus, P. \& Zaichkowsky, J. L. (2021). The Convenience of Shopping Via Voice AI: Introducing AIDM. Journal of Retailing and Consumer Sevices, 102490. https://doi.org/10.1016/j.jretconser.2021.102490

Lee, J., Long, A., Mcrae, M., Steiner, J. \& Handler, S. G. (2015). Bitcoin Basics: A Primer on Virtual Currencies. Business Law International, 16(1), 21-48.

Mauldin J. (2014). Is Bitcoin the Future. www.forbes.com, www.forbes.com/sites/johnmauldin/2014/12/01/is-bitcoin-the-future

Medida, R. S. S. (2020). Scope of Blockchain Technology in the Retail Industry. International Journal of Computer Engineering and Technology, 11(3).

Midgley, D. F. \& Dowling, G. R. (1978). Innovativeness: The Concept and Its Measurement. Journal of Consumer Research, 4(4), 229-242.

Nakamoto, S. (2008). Bitcoin: A Peer-to-Peer Electronic Cash System. Satoshi Nakamoto Institute, https://nakamotoinstitute.org/bitcoin/

Polasik, M., Piotrowska, A. I., Wisnieuwski, T. P., Kotkowski, R. \& Lightfoot, G. (2015). Price Fluctuations and the Use of Bitcoin: An Empirical Enquiry. Int. J. Electron. Commerce 20(1), 9-49. https://doi.org/10.1080/10864415.2016.1061413

Presthus, W. \& O'malley, N. O. (2017). Motivations and Barriers for End-User Adoption of Bitcoin as Digital Currency. Procedia Computer Science, 121, 89-97. https://doi.org/10.1016/j.procs.2017.11.013

Priporas, C. V. \& Mylona, I. (2008). Mobile Services: Potentiality of SMS as New Business Communication Tool in Attracting Consumers. International Journal of Mobile Communications, 6(4), 456-466. https://doi.org/10.1504/IJMC.2008.018053

Redshaw, T. (2017). Bitcoin Beyond Ambivalence; Popular Rationalization and Feenberg's Technical Politics. Thesis Eleven, 138(1), 46-64.

Roehrich, G. (2004). Consumer Innovativeness: Concepts and Measurements. Journal of Business Research, 57(6), 671-677. 
Volkan TEMizKAN, M. Ali YETGíN \& Kasım YILMAZ, 2022, Cilt: 23, Sayı: 1, ss. 25-48.

Rogers, E. M. (1995). Diffusion of Innovations. Free Press, New York, 4.

Rogers, E. M. (2003). Diffusion of Innovations. New York: Free Press, 5.

Rogers E. M. (1995). Diffusion of Innovations: Modifications of a Model for Telecommunications. In: Stoetzer MW., Mahler A. (eds) Die Diffusion Von Innovationen in der Telekommunikation. Schriftenreihe des Wissenschaftlichen Instituts für Kommunikationsdienste, vol 17. Springer, Berlin, Heidelberg. https://doi.org/10.1007/9783-642-79868-9_2

Ron, D. \& Shamir, A. (2013). Quantitative Analysis of the Full Bitcoin Transaction Graph. In International Conference on Financial Cryptography and Data Security, 6-24, Springer, Berlin, Heidelberg.

Roussou, I. \& Stiakakıs, E. (2016). Adoption of Digital Currencies by Companies in the European Union: A Research Model Combining DOI and TAM. In 4 the International Conference on Contemporary Marketing Issues (ICCMI) June 22-24, 2016 Heraklion, Greece, 163.

Sahin, I. (2006). Detailed Review of Rogers' Diffusion of Innovations Theory and Educational Technology-Related Studies Based on Rogers' Theory. Turkish Online Journal of Educational Technology, 5(2), 14-23.

Schlegel, M., Zavolokina, L. \& Schwabe, G. (2018). Blockchain Technologies from the Consumers' Perspective: What is There and Why Should Who Care? In Proceedings of the 51st Hawaii International Conference on System Sciences, 3477.

Schuh, S. \& Shy, O. (2016). US Consumers' Adoption and Use of Bitcoin and Other Virtual Currencies, In DeNederlandsche Bank. Conference Entitled Retail Payments: Mapping Out the Road Ahead.

Shahzad, F., Xıu, G., Wang, J. \& Shahbaz, M. (2018). An Empirical Investigation on the Adoption of Cryptocurrencies Among the People of Mainland China. Technology in Society. 55, 3340. https://doi.org/10.1016/j.techsoc.2018.05.006.

Sherry, L. (1997). The Boulder Valley Internet Project: Lessons Learned. THE (Technological Horizons in Education) Journal, 25(2), 68-73.

Silinskyte, J. (2014). Understanding Bitcoin Adoption: Unified Theory of Acceptance and Use of Technology (UTAUT) Application. Master Thesis, University Leiden, ICT in Business.

Tsanidis, C., Nerantzaki, D. M., Karavasilis, G., Vrana, V. \& Pashaloudis, D. (2015). Greek Consumers and the Use of Bitcoin. The Business \& Management Review, 6(2), 295-302.

Tu, K. V. \& Meredith, M. W. (2015). Rethinking Virtual Currency Regulation in the Bitcoin Age. Wash. Law. Rev., 90, 271-347.

Vora, G. (2015). Cryptocurrencies: Are Disruptive Financial Innovations Here?. Modern Economy, 6(07), 816.

White, R., Marınakıs, Y., Islam, N. \& Walsh, S. (2020). Is Bitcoin a Currency, a Technology-Based Product, or Something else?. Technological Forecasting and Social Change, 151, 119877. https://doi.org/10.1016/j.techfore.2019.119877

Wonglimpiyarat, J. (2016). Bitcoin: The Revolution of the Payment System?. Journal of Payments Strategy \& Systems, 9(4), 230-240. 
World Economic Forum (2021). These are the Countries Where Cryptocurrency Use is Most Common, Statista Global Consumer Survey, Katharina Buchholz, Data Journalist, Statista, https://www.weforum.org/agenda/2021/02/how-common-is-cryptocurrency/

Yoo, K., Baê, K., Park, E. \& Yang, T. (2020). Understanding the Diffusion and Adoption of Bitcoin Transaction Services: The Integrated Approach. Telematics and Informatics, 53, 101302. https://doi.org/10.1016/j.tele.2019.101302 
Volkan TEMizKAN, M. Ali YETGíN \& Kasım YILMAZ, 2022, Cilt: 23, Sayı: 1, ss. 25-48.

\section{EXTENDED ABSTRACT}

The encryption method used by Blockchain technology provided higher reliability than others, and thus, it has paved the way for crypto-based payments, money transfer solutions, and crypto coins. Today, many businesses are considering cryptocurrencies as a payment method and applying Blockchain technology to their operations. Due to legal uncertainty in many countries, financial institutions are hesitant to accept cryptocurrencies as payment methods. However, this trend seems to be changing worldwide lately because of new laws and technological tools. When the functionality dimensions of the crypto money use are examined, it is seen that consumers care about the transfer fee and speed rather than the stability of the crypto Money used. Regarding intention to buy with crypto money, consumers are found to be willing to buy products or services with cryptocurrencies due to advantages and conveniences such as the reduced risk of carrying money, the possibility of making faster and lower commission fee transfers, making transactions on national and international markets without using brokers. (Ciaian and Rajcaniova, 2016). Also, businesses are inclined to accept cryptocurrency payments and traditional payment methods to attract the attention of new generation consumers and achieve positive results on sales and marketing efforts (Vora, 2015; Andrei et. all, 2019).

Internationally virtual currency use adoption level is low because of the negative perceptions on legal support, trust and experience. Trust can be formed faster when governments better regulate and ensure virtual currencies (Albayati et al., 2020). It is predicted that the legislation accepted in the Congress of the United States of America will play a vital role in shaping the future of virtual currencies (Lee et al., 2015). Germany has already allowed several cryptocurrencies to be exchanged between retailers and consumers (Arli et al., 2020). The literature survey shows that consumers still have reservations about easily adapting to virtual money use in retailing and online shopping perception of trust regarding the use of virtual money in retailing and online shopping.

The main purpose of this study is to search the customer behaviors and motives behind virtual money use decisions in retailing. In this study, the reasons why retail sectors add virtual currency payment options among traditional ones, how the capability of shopping with digital money affects the consumer decision-making process have been investigated. The problematics of this research include the reasons for retail businesses to switch to the cryptocurrency payment system, the benefits of this system to the consumers, the advantages of virtual money payments to retailing, the prospective perception of the status of virtual money, and the problems faced by the retailer and the consumers in the transactions of virtual money payments.

In the study, a qualitative approach was implemented (Priporas and Mylona, 2008) with an exploratory (Creswell, 2014) and interpretive point of view (Gray, 2013). NVivo 11 Program was used in this research. The theoretical framework of the study was formed on Rogers's Theory of Diffusion of Innovation. According to the theory presented by Rogers (1995), an idea, practice, or an object perceived as new in individual and organizational approach is defined as innovation (Rogers, 1995). According to the theory, innovation adoption consists of a five-stage process depending on accepting or not accepting the decision (Rogers, 1995). Each stage of this process makes the final decision by reducing uncertainty regarding innovation and advancing (Rogers, 2003). In this context, 45-minute interviews were conducted with participating companies over the Zoom Video-conference application program to understand the customer experiences of retailers using cryptocurrency. The findings obtained were analyzed in the context of Rogers's Theory of Diffusion of Innovation. 
The meeting request e-mails were sent to 79 enterprises (Coin-Turk Report Business List, 2021) from different sectors which accept cryptocurrency payments.After the first wave of e-mails, five businesses agreed to participate in the online meeting, while four more agreed to join in the second week. To increase this number, based on the news on cryptocurrency use in retailing, 40 more businesses in Europe and USA that accept cryptocurrency payments have been contacted via e-mail. We could not get any affirmative responses from foreign companies. The nine companies that accepted the interview were informed that the interviews were to be conducted via Zoom program through video conference, and permission was taken to record the interview data so that the interview data could be analyzed descriptively. 45-minute interviews were held with nine company officials who answered all questions between February 25th, 2021, and February 28th, 2021.

The significant findings of this study included the following results. Businesses offer their international customers the option to pay with digital currencies to perform faster money transfers at a lower cost. Business owners and consumers believe that more governmental regulations should intervene with digital currency usage. The common desire of buyers and sellers is a reliable and internationally recognized digital currency which facilitates trade. Generations $\mathrm{Y}$ and $\mathrm{Z}$, in particular, have adopted digital currency very fast. These generations like to use a common currency with international validity that they can use everywhere. They like to make the purchase quickly and practically without any obstacles. The fact that businesses offer different payment methods increases customer satisfaction. In particular, receiving payments with cryptocurrencies attracts the attention of consumers. For this reason, it is a good advertising tool as it increases the recognition of the businesses. Also, it inspires and supports an innovative and technology-driven business image on customers.

There are many customers using cryptocurrency for investment. They may want to use cryptocurrency for shopping too. Businesses that accept cryptocurrency payments are the ones that can answer the needs of those customers. This payment option and capability increase customer satisfaction. This study primarily contributes to the literature in two ways. First in-depth interviews with pioneer business managers who accept cryptocurrency at national and international trade enabled researchers to offer a model about cryptocurrency use motivation (Figure 2). As a result of this research, cryptocurrency using technology must meet three requirements to be an accustomed payment method. These requirements include; High transaction speed, high transaction security, and low transfer fees. This model is the first in the literature which depicts the features of cryptocurrency usage at national and international shopping applications. The customers' shopping experiences were examined from the seller's point of view. This study explores the experiences of the retailers accepting cryptocurrency for their business transactions with an in-depth interview method. This method allows researchers to obtain more detailed information about retailers' experiences, including their emotions, expressions, and perspectives that are otherwise very difficult to be explored. Thus, this study will contribute to future empirical studies on this subject. 